\title{
Economic sustainability of agricultural holdings in Poland in the context of their environmental impact
}

\author{
Wioletta Wrzaszcz ${ }^{1}$, PhD; Professor Józef St. Zegar², PhD
}

\begin{abstract}
Sustainability of agriculture and agricultural farms is the subject of increasing interests of society and researchers. The main problem of this issue is appropriate methodology of measuring agriculture sustainability, due to its complexity. Different proposals are presented and discussed, and still, there is no generally accepted measures of agriculture sustainability. This problem also concerns agricultural holdings` economic and environment sustainability examination. The particular dilemma is to define modes of agricultural techniques and technologies, that make it possible to combine economic and environmental objectives of agricultural holdings. The purpose of the article is economic sustainability evaluation of agricultural holdings in Poland taking into consideration their potential environmental impact. There were analysed a few groups of farms with potentially different environment impact, namely: a) ecological - organized according with EU legal rules; b) specialized in livestock production; c) not-specialized, with mixed plant and livestock production. Economic sustainability was calculated on the basis of productive and economic indicators, considering subsidies connected with Common Agricultural Policy. The analysis was based on Farm Accountancy Data Network 2004 and 2013.
\end{abstract}

Keywords: farms`sustainability, economic sustainability, agriculture environmental impact, Farm Accountancy Data Network, Poland

\section{Introduction}

The European Union took a course on sustainable agricultural and rural development, in order to meet the challenges of modern development. This is directly or indirectly served by the Common Agricultural Policy (CAP) instruments and the European Union's policy instruments in other fields. An analysis of the CAP evolution points to the intensification of the instruments aimed at the sustainability of agriculture and rural areas (Kociszewski, 2014; Krzyżanowski, 2015), however, progress in the sustainability differs from the societal expectations. The globalisation phenomena, competitiveness requirement and efficiency pressure often result in sacrificing the sustainability for the sake of microeconomic interests and current benefits.

In sustainable agriculture and rural development, a special place is occupied by family farms, which, despite the pressure of agri-industrial corporations, strengthening of the global food system and activity of cultural mega-trends, still are a basic organisational form of agriculture, being a socially attractive way of agricultural production, in particular reconciling an increase in agricultural production with care of the natural and sociocultural environment (Woś, Zegar, 2002; Ploeg, 2009).

For many reasons, measuring the sustainability of farms, as well as of agriculture, is

\footnotetext{
${ }^{1}$ Institute of Agricultural and Food Economics - National Research Institute, General Economic
}

Department, 00-002 Warsaw, Świętokrzyska 20, Poland.

2 Institute of Agricultural and Food Economics - National Research Institute, General Economic

Department, 00-002 Warsaw, Świętokrzyska 20, Poland. 
complex, as indicated by numerous studies on the sustainability of agriculture and farms (Zegar, 2012; Zegar (ed.), 2013; Wrzaszcz, 2014; Wrzaszcz, Zegar, 2014; Wrzaszcz, Prandecki, 2015). With regard to three generally distinguished aspects of sustainability environmental, economic and social - many measurement indicators have been formulated, whereby major importance is attached to the environmental sustainability, while smaller - to the economic and social sustainability. In case of farms, the economic sustainability is particularly important because it is associated with the basic economic objective of farmers and motive of their economic activities along with the farm's contribution to food security and overall economic growth. In addition to the autonomous market mechanisms, the farms' economic results specifying the values of economic sustainability indicators are also determined by a political factor which, through certain instruments, directly and indirectly affects these results.

The objective of the article is an attempt to determine the impact of the Common Agricultural Policy (CAP) on the selected indicators of the economic sustainability of farms in Poland, taking into account their potential environmental impact.

\section{Research method}

The study is based on a panel of farms covered by the FADN system (Farm Accountancy Data Network) and keeping agricultural accounting on a continued basis in the years 2004-2013. This group consisted of more than 4.5 thousand farms. The period covered by the analysis is dictated by the objective of the study and the data availability. The first year of this period presents a situation in which the effects of the implemented CAP mechanisms were insignificant, while in the final year we may believe that those effects have already manifested themselves all their glory. Within the panel of the farms, three groups of farms have been distinguished, namely: organic, with mixed production and specialist in livestock production. These groups may be treated of sets of farms differing in terms of their environmental friendliness and are presented against a background of farms in general.

Organic farms included also those which have an organic production certificate or are under reorganisation. The rules of functioning of farms in this system are fixed by law. Agricultural production in these farms is based on the use of natural ecosystem processes and is conducted with the minimal use of industrial means of agricultural production.

The group of non-specialist (mixed production) farms include farms with mixed crop and livestock production. According to the FADN classification, this applies to type 8 farms ${ }^{1}$. In the light of the sustainable development, farms with mixed production are a very desirable group, as a combination of crop and livestock production enables a closed cycle of nutrients in the farm-environment system just as it was in traditional agriculture. Farms with mixed production exert relatively smaller pressure on the natural environment.

${ }^{1}$ The following types of agricultural holdings are specified in FADN (general types, according to the GTF classification): specialist in field crops (type 1), specialist in horticulture (type 2), specialist in permanent crops (type 3), specialist in rearing grazing livestock (type 4), specialist in rearing granivores (type 5), non-specialist with mixed crops (type 6), non-specialist with mixed livestock (type 7), non-specialist with mixed crops and livestock (type 8), (Goraj, Mańko, 2009). 
The group of livestock farms includes farms specialised in livestock production (mainly in cattle rearing and breeding and rearing of granivores), which in the FADN system are classified as type 4 and 5. Those farms, due to the limitation of crop production and specialisation in livestock production, may generate greater environmental external costs. A particularly negative impact is exerted by farms with highly intensive livestock production, rearing animals mainly or solely on a basis of purchased feed resulting in local pollution of individual components of the environment - soil, water and air - due to the large amount of manure produced and gases generated (mainly methane and ammonia) ${ }^{2}$.

The distinguished groups of farms have been assessed in terms of their economic sustainability, using indicators of productivity and profitability of the factors of production. The productivity of the factors of production is a basic element of the economic efficiency of the farm. It is defined as a ratio of a single output and a single input. It may refer to the individual factors of agricultural production (land, labour and capital) and also to those factors in general. Its level may result from increasing production (maximising outputs) or reducing costs (minimising inputs). The profitability of the factors of production, on the other hand, is the basic output indicator of the agricultural activity, indicating the size of income earned from a unit of a given input. Farm income is a basic economic objective of the farmer's activity and is an important determinant of the standard of life of a farming family, hence it may be an important indicator of the economic sustainability (Wrzaszcz, Zegar, 2014). The size of income illustrates the level of remuneration for involving own factors of production in the farm's operations and for risk taken by the farm holder during the accounting year.

In order to examine the productivity and profitability of the factors of production in the selected groups of farms, the following selected indicators have been used ${ }^{3}$ :

\section{- Land Productivity.:}

$\checkmark$ Total Output (TO)/Agricultural Land

$\checkmark$ Gross Farm Income (GFI) / Agricultural Land

- Labour Productivity:

$\checkmark$ Total Output (TO) /Annual Work Unit (AWU)

$\checkmark$ Gross Farm Income (GFI)/Annual Work Unit (AWU)

2 In case of the large concentration (industrial farms), there is a problem of odour, animal welfare as well as the quality of products of animal origin due to the use of, inter alia, steroids and antibiotics.

3 *The Total Output of a farm represents the basic economic and production category that indicates the economic result of farming. It is the outcome of the sum of the value of crop and livestock production and other activities.

${ }^{*}$ Gross Farm Income is the result of difference of Total Output and the Total Intermediate Consumption (Total specific costs - including inputs produced on the holding - and overheads arising from production in the accounting year), adjusted for the outcome of the balance of current subsidies and taxes. This value indirectly makes it possible to verify the impact of farming efficiency measured by the level of costs and subsidies.

*Family Farm Income is the primary economic goal of farmer's activity and it is an essential determinant of a farmer family living standard, and hence it may be an important indicator of farm efficiency in agriculture.

*1 AWU (Annual Work Unit) is equivalent to full-time own and paid labour, i.e. 2,120 hours of work a year.

*1 FWU (Family Work Unit) is the equivalent of a full-time labour of a farming family member. 
- Land Profitability: Family Farm Income (FFI)/Agricultural Land

- Labour Profitability: Family Farm Income (FFI)/Family Work Unit (FWU).

\section{Research results}

The synthetic characteristics of analysed farms has been included in Table 1 . In the period 2004-2013, the area of an average farm increased by $20 \%$, of labour inputs by $0.2 \%$ and of the headage of animals 4 by $9 \%$. The value of assets (total assets) increased by 2.6 times, whereby this increase refers mainly to fixed assets (machinery, buildings and structures, land), whose share in the balance sheet increased from $82 \%$ to $89 \% 5$.

Increasing the production potential contributed to an increase in the value of agricultural production of the farm by $77 \%$ (per 1 ha of AL by $48 \%$ ) and in the gross value added it amounted to $96 \%$. In the first case, the major impact has been exerted by a change in the area of agricultural land and livestock, and in the second - subsidies to the farm's operations. Farm income increased more than twice.

The improving economic situation of farms has been reflected in investments made by agricultural producers, which increased significantly.

Data for farms in general are a reference point for three groups of farms distinguished within the panel, which in 2004 and 2013 were eligible for being included in a specific group. The number of organic farms in 2004 accounted for only $1.3 \%$ of farms within the panel, of farms with mixed production $-34 \%$ and of livestock farms $-26 \%$. Over the analysed period, the size of the group of organic farms increased (by 122\%) and of livestock farms (28\%), while the number of farms with mixed production decreased (by $22 \%$ ). The growth in the population of organic farms should be rated positively, while a decrease in the number of farms with mixed production and an increase in the number of livestock farms may be alarming as this entails the growing dependence of livestock production on the feed industry, growing risk of pollution of environmental components and the greater consumption of natural resources.

Figure 1 illustrates the relative changes which have taken place in the distinguished groups of farms in relation to the changes in farms within the panel in general. Farms specialised in livestock production slightly decreased their advantage over the average farm within the panel as regards the basic production and economic categories (apart from the area of AL), however, it is still significant. This indicates that specialist livestock production is more beneficial for the agricultural producer, than mixed or organic production. On the other hand, both organic farms and farms with mixed production significantly deviate in minus from farms within the panel in general, both in terms of the production potential, production value and the size of farm income. The largest gap in this respect existed between organic farms and average farms. In case of the income category, that difference was largest and amounted to more than $60 \%$ in 2004 . Changes taking place in the group of organic farms partially reduced those differences, mainly in

${ }^{4}$ The headage of animals has been expressed in Livestock Unit (LU), where $1 \mathrm{LU}$ is a standard unit of farm animals weighing $500 \mathrm{~kg}$.

5 All value categories were presented in current prices. The EUR/PLN exchange rate of EUR 1=PLN 3.90916 was used. This exchange rate is applicable in the FADN system to determine the standard values in EUR. 
the area of agricultural land, as well as the economic results. The gap in terms of the production value has not changed, however, it declined by almost half in case of income. It happened undoubtedly thanks to support for organic production in the form of subsidies addressed to this agricultural production system. However, it should be stressed that the production and economic gap of this group of farms is still significant in case of income it is $30 \%$ (2013). The difference in terms of the assets value was growing, which indicated a faster rate of changes in this regard in case of average farms when compared to organic farms. It may be assumed that due to the lower economic results, organic farms are not able to increase assets at the same rate as average farms. Organic farms' income was insufficient to make expensive and requiring - often longterm - economic investments.

Against a background of these changes, a question arises as to the environmental and economic effectiveness of the existing instruments of support for agricultural producers, guided by the thought of sustainable development. As shown by the data presented, the balance of outputs is negative, both in environmental (as indicated by the decreasing number of farms with mixed production and the progressive process of specialisation) and economic terms (increasing production and economic gap).

Table 1. Farms`characteristic (average per farm)

\begin{tabular}{|c|c|c|c|c|c|c|c|c|c|}
\hline \multirow{2}{*}{ No. } & \multirow{2}{*}{ Specification } & \multicolumn{2}{|c|}{ Total } & \multicolumn{2}{|c|}{ Organic } & \multicolumn{2}{|c|}{ Mixed } & \multicolumn{2}{|c|}{ Livestock } \\
\hline & & 2004 & 2013 & 2004 & 2013 & 2004 & 2013 & 2004 & 2013 \\
\hline 1 & Farms` number & 4579 & 4579 & 60 & 133 & 1549 & 1219 & 1211 & 1547 \\
\hline 2 & Agricultural Land (ha) & 30.38 & 36.02 & 19.58 & 29.87 & 28.77 & 33.22 & 27.82 & 32.56 \\
\hline 3 & Labour Input (AWU) & 2.04 & 2.08 & 2.06 & 1.84 & 1.87 & 1.86 & 1.99 & 2.09 \\
\hline 4 & Livestock Unit (LU) & 27.72 & 30.20 & 10.90 & 12.59 & 22.73 & 25.12 & 52.56 & 58.31 \\
\hline 5 & Assets (thousand $€$ ) & 123.34 & 326.46 & 79.64 & 190.02 & 104.67 & 278.77 & 140.88 & 342.11 \\
\hline 6 & $\begin{array}{l}\text { Total Output } \\
\text { (thousand } € \text { ) }\end{array}$ & 40.89 & 72.33 & 17.82 & 29.62 & 33.30 & 54.27 & 53.83 & 95.67 \\
\hline 7 & $\begin{array}{l}\text { Gross Farm Income } \\
\text { (thousand } € \text { ) }\end{array}$ & 18.81 & 36.77 & 9.72 & 25.05 & 15.26 & 27.10 & 23.28 & 42.83 \\
\hline 8 & $\begin{array}{l}\text { Family Farm Income } \\
\text { (thousand } € \text { ) }\end{array}$ & 11.81 & 25.28 & 4.63 & 17.88 & 9.79 & 18.48 & 16.37 & 31.37 \\
\hline 9 & $\begin{array}{l}\text { Gross value of } \\
\text { investment } \\
\text { (thousand } € \text { ) }\end{array}$ & 5.38 & 14.03 & 3.88 & 5.45 & 3.58 & 10.04 & 6.08 & 13.89 \\
\hline 10 & $\begin{array}{l}\text { Net value of } \\
\text { investment } \\
\text { (thousand } € \text { ) }\end{array}$ & 0.40 & 5.14 & 0.31 & 0.04 & -0.68 & 3.07 & 1.05 & 4.32 \\
\hline
\end{tabular}

Source: Prepared on the basis of 2004-2013 FADN data. 


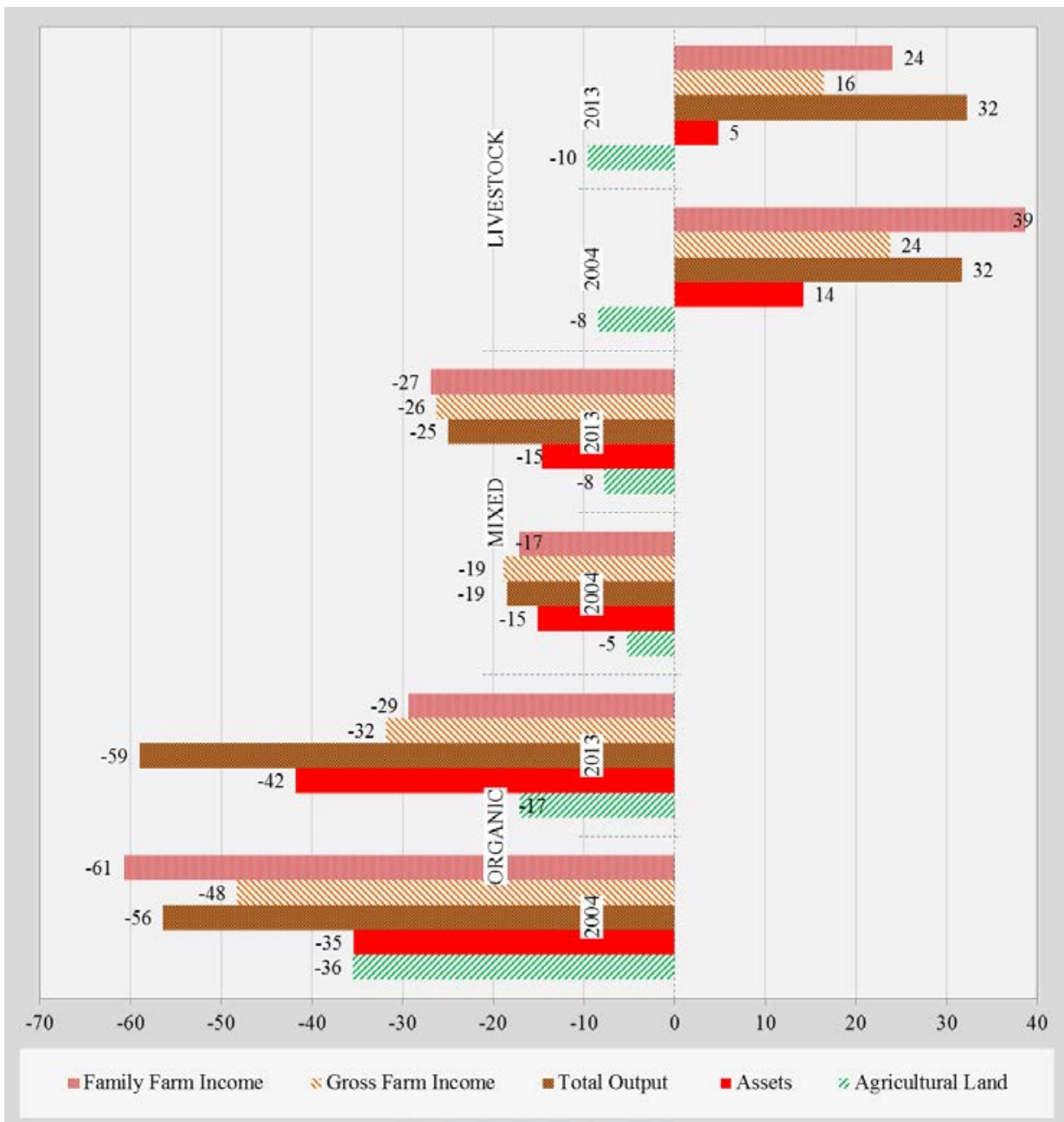

Figure 1. The relative difference (\%) between the farms' groups

Source: Prepared on the basis of 2004-2013 FADN data.

The values of the selected economic sustainability indicators of farms are presented in Figure 2. The land productivity in the average farm within the panel was at the level of EUR 1.3 thousand/ha in 2004, while in 2013 it rose to the level of EUR 2.0 thousand/ha and was higher by about half when compared to its initial value. Organic farms and farms with mixed production achieved the results lower by, respectively, 31 and $8 \%$ in 2004, while in 2013 those differences even increased, to 50 and $20 \%$, respectively. The data presented indicate the large gap with regard to the land productivity among average farms and more environmentally-friendly farms. Organic farms achieve particularly low results, which, although slightly improved, but the gap between them and average farms increased. We should stress the fact that farms specialised in livestock production are unrivalled in this regard, which is visible both in static terms when we compare the differences of the values in specific years (in relation 
to the average, it was 46\% in 2004 and 45\% in 2013), as well as in dynamic terms, taking into account the rate of increase in the land productivity (the results in 2013 were higher by as much as $53 \%$ when compared to 2004 ).

The land productivity indicators based on the gross value added also indicated the improved economic sustainability of all groups of farms. The land productivity in these terms is increasing fastest in case of organic farms, thanks to financial support for this production system and the differences in prices of organic and conventional products.

The ratio of the farm income value to the area used for agricultural purposes informs us of the land input profitability. Average income per area unit was EUR 400/ha in 2004 and rose to the level of EUR 700/ha in 2013, i.e. by $75 \%$ over the analysed period. Organic farms and farms with mixed production achieved the lower economic results when compared to average farms, although the negative difference in case of organic farms decreased. Specialist livestock farms, just like with regard to the land productivity, were leaders in terms of the value of this indicator. In case of this group of farms, despite the increase in the land profitability, their advantage over average farms decreased. These relations were significantly affected by subsidies to the farm's operations (used to a larger extent by organic farms and farms with mixed production), as well as by the costs, inter alia, related to payment for external factors (much larger in case of livestock farms, Table 2).

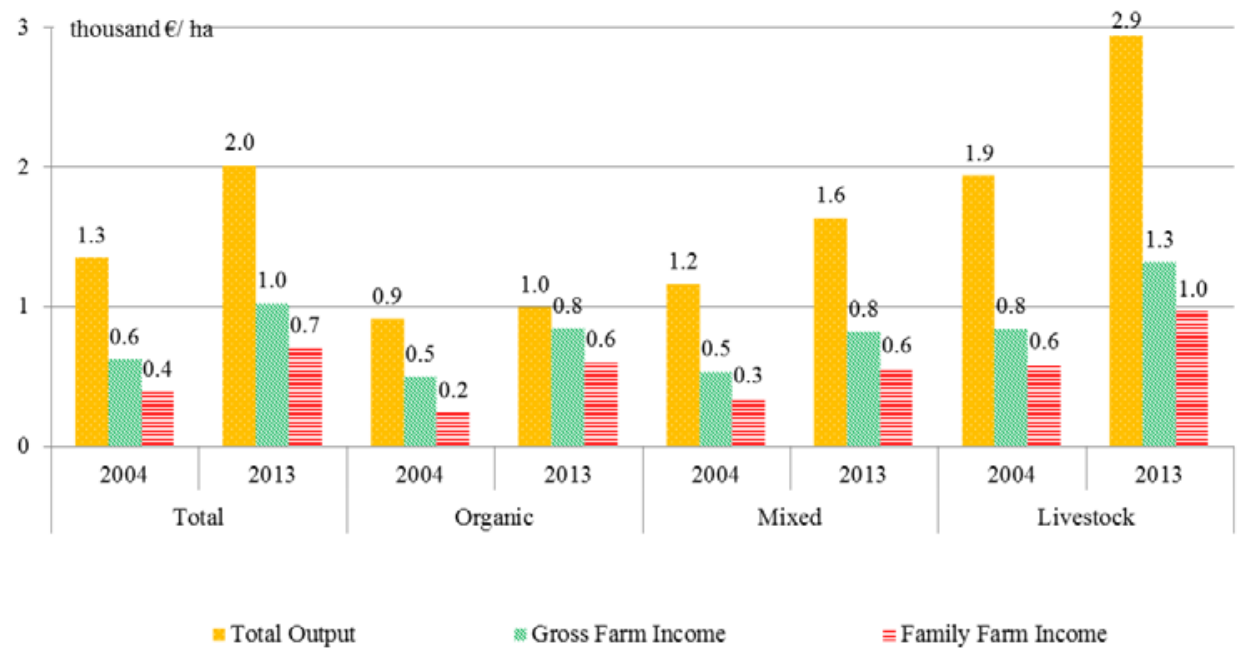

Figure 2. Productivity and profitability of land in analysed farms 'groups

Source: Prepared on the basis of 2004-2013 FADN data. 
Table 2. Selected economic indicators (thousand $€ /$ ha)

\begin{tabular}{|c|l|r|r|r|r|r|r|r|r|}
\hline \multirow{2}{*}{ No. } & \multicolumn{2}{|c|}{ Specification } & \multicolumn{2}{|c|}{ Total } & \multicolumn{2}{c|}{ Organic } & \multicolumn{2}{c|}{ Mixed } & \multicolumn{2}{c|}{ Livestock } \\
\cline { 3 - 10 } & & $\mathbf{2 0 0 4}$ & $\mathbf{2 0 1 3}$ & $\mathbf{2 0 0 4}$ & $\mathbf{2 0 1 3}$ & $\mathbf{2 0 0 4}$ & $\mathbf{2 0 1 3}$ & $\mathbf{2 0 0 4}$ & $\mathbf{2 0 1 3}$ \\
\hline 1 & Intermediate consumption & 0.77 & 1.26 & 0.46 & 0.57 & 0.67 & 1.10 & 1.15 & 1.90 \\
2 & Balance of subsidies and taxes & 0.04 & 0.28 & 0.04 & 0.41 & 0.05 & 0.28 & 0.05 & 0.28 \\
& to operational activities & & & & & & & & \\
3 & Depreciation & 0.16 & 0.25 & 0.18 & 0.18 & 0.15 & 0.21 & 0.18 & 0.29 \\
\hline 4 & Total external factors & 0.05 & 0.10 & 0.05 & 0.07 & 0.03 & 0.07 & 0.05 & 0.09 \\
\hline
\end{tabular}

Source: Prepared on the basis of 2004-2013 FADN data.

The labour productivity based on the production value amounted to EUR 20 thousand/ AWU in 2004 and by 2013 it increased by 75\%, reaching a level of EUR 35 thousand/AWU (Figure 3). Just like in case of the land productivity, organic farms and farms with mixed production were inferior to average farms, while specialist livestock farms were characterised by the highest labour productivity. These relations also confirm the values of indicators based on other production and economic categories. Particularly outstanding in this regard were organic farms. In their case, this could also be the result of reducing labour inputs and increasing labour intensity in organic farms.

The labour profitability in the average farm increased twice in the period 2004-2013, from EUR 7 thousand/FWU to EUR 14 thousand/FWU. Similar changes have taken place in farms with mixed production and livestock farms. The scale of changes in the land profitability in the indicated groups was not so impressive. The even greater increase in the labour profitability was characteristic of organic farms, as it was about 3.7 times. In case of this group of farms, a particularly important factor was an increase in subsidies to the farm's operations.

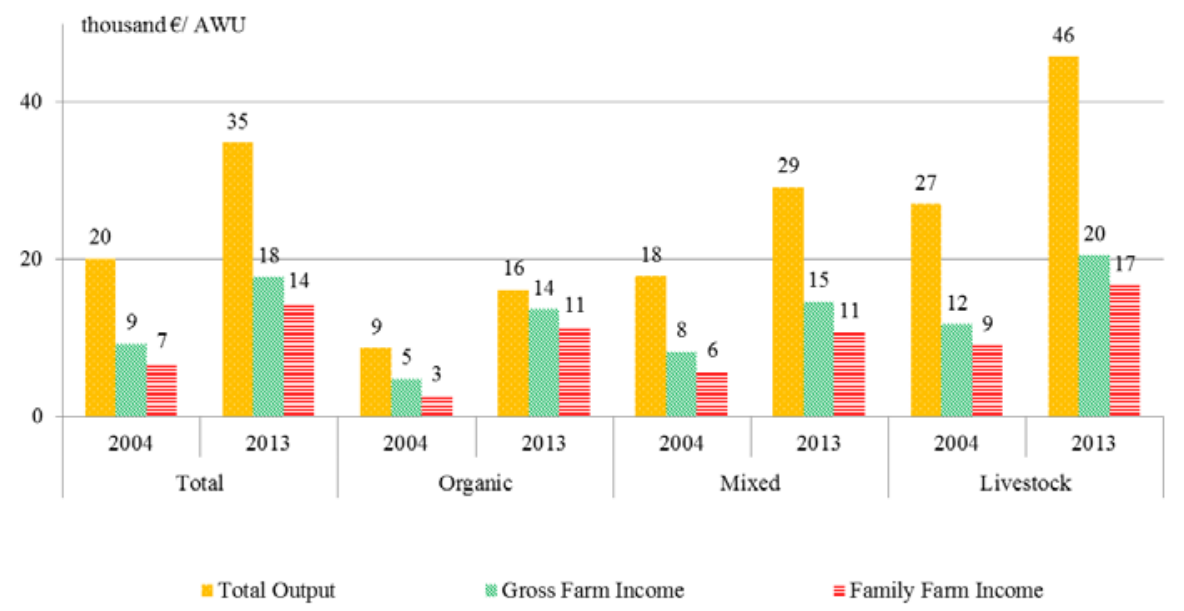

Figure 3. Productivity and profitability of labour in analysed farms` groups

Source: Prepared on the basis of 2004-2013 FADN data. 


\section{Subsidies}

Subsidies addressed to farms are essential for their economic results and sustainability. Each support for agricultural producers in the form of subsidies requires the obligatory introduction of specific environmental practices (cross-compliance principles, greening, practices assigned to the specific measures of the Rural Development Programme - RDP). In connection with the fact that these subsidies are diversified, we used their selected categories and aggregated values. We presented their average value per farm and selected relations with regard to the results.

Table 3 summarises the data on subsidies, which were addressed to farms in 2004 and 2013. In 2004, the average farm received subsidies in the amount of EUR 1.4 thousand which were in whole associated with its operations (at that time, subsidies supporting the investment activity have not been launched yet). They included mainly direct subsidies (almost 3/4), while the rest accounted for transfers within the framework of the Rural Development Programme's measures. In 2004, some packages of the agri-environmental programme, addressed to organic farms, were introduced, so was support for farms located in less-favoured areas (LFAs).

In 2004 , the ratio of subsidies to production amounted to $3.5 \%$ only. The balance of subsidies and taxes to the farm's operations in the gross value added was $7 \%$, while the balance of subsidies and taxes in total in the value of income amounted to $8 \%$. The implementation of the CAP has significantly changed that situation - in 2013, the average farm received EUR 12.1 thousand of subsidies - almost 8.5 times more than in 2004. The essential part of those transfers were direct subsidies (65\%). In 2013, support for rural development covered various measures proposed to farmers, hence subsidies under the RDP accounted for 35\% of the total value of those transfers. It may be concluded that farmers showed interest in taking environmentally-friendly measures - as evidenced by the high share of subsidies provided to farmers for agri-environmental projects $-24 \%$ (almost half related to organic production), while 18\% of LFA support (adopting that all transfers under the RDP as 100\%).

The indicators of the ratio of subsidies to the production and economic results illustrate their increasing role in shaping the economic results of farms. The indicator of the ratio of all subsidies to the farm's production amounted to $17 \%$, of the balance of subsidies and taxes relating to the farm's operations to the gross value added $-27 \%$, while of the balance of total subsidies and taxes to farm income $-36 \%$. Linking subsidies with the observance of the environmental protection principles in agricultural production also affected the environmental sustainability of farms. 
Table 3. Subsidies (average per farm, thousand $€$ ) and their relations to farms`outcomes (\%)

\begin{tabular}{|c|l|r|r|r|r|r|r|r|r|}
\hline \multirow{2}{*}{ No. } & \multicolumn{2}{|c|}{ Specification } & \multicolumn{2}{c|}{ Total } & \multicolumn{2}{c|}{ Organic } & \multicolumn{2}{c|}{ Mixed } & \multicolumn{2}{c|}{ Livestock } \\
\cline { 3 - 10 } & & $\mathbf{2 0 0 4}$ & $\mathbf{2 0 1 3}$ & $\mathbf{2 0 0 4}$ & $\mathbf{2 0 1 3}$ & $\mathbf{2 0 0 4}$ & $\mathbf{2 0 1 3}$ & $\mathbf{2 0 0 4}$ & $\mathbf{2 0 1 3}$ \\
\hline 1 & Total subsidies (TS) & 1.44 & 12.13 & 1.09 & 13.54 & 1.53 & 11.15 & 1.21 & 11.10 \\
2 & - to operational activities (OA) & 1.44 & 10.94 & 1.09 & 13.00 & 1.53 & 10.29 & 1.21 & 9.45 \\
3 & - to investment activities (OI) & 0.00 & 1.18 & 0.00 & 0.55 & 0.00 & 0.86 & 0.00 & 1.64 \\
4 & Direct payments & 1.05 & 7.92 & 0.43 & 6.70 & 1.22 & 7.31 & 0.65 & 7.12 \\
5 & Subsidies to rural development & 0.39 & 4.21 & 0.66 & 6.84 & 0.31 & 3.84 & 0.56 & 3.98 \\
6 & - agrienvironmental & 0.01 & 1.03 & 0.37 & 4.62 & 0.00 & 1.02 & 0.00 & 0.71 \\
7 & - less favoured areas & 0.05 & 0.77 & 0.04 & 1.15 & 0.04 & 0.67 & 0.07 & 1.01 \\
\hline 8 & Total subsidies $/$ TO & 3.52 & 16.77 & 6.13 & 45.73 & 4.60 & 20.55 & 2.25 & 11.60 \\
9 & Balance of OA and T*/GFI & 6.92 & 27.17 & 8.46 & 49.35 & 8.75 & 34.95 & 6.50 & 21.21 \\
10 & Balance of TS and T*/FFI & 7.95 & 35.99 & 7.33 & 66.84 & 11.31 & 47.49 & 6.83 & 27.21 \\
\hline
\end{tabular}

*T-taxes.

Source: Prepared on the basis of 2004-2013 FADN data.

Organic farms in 2004 were inferior to farms in general (and to farms from other distinguished groups) in terms of the amount of subsidies while by 2013 they gained some advantage. The structure of subsidies in organic farms definitely differed from the same structure in average farms as over the analysed period organic farms received a greater part of the funds from the RDP - they were covered by the agri-environmental programme. In 2013, the funds obtained in that regard amounted to, respectively, 56\% and 68\% in 2013 of all transfers obtained from the RDP. Organic farms acquired relatively small subsidies for their investment activity, which may also indirectly indicate limited investments.

The indicators of the ratio of subsidies to the results of organic farms show a definitely greater role of external transfers in shaping their economic situation in relation to average farms.

In case of farms with mixed production, the average amount of subsidies, their change over time, as well as the sectoral structure did not differ significantly from the amount for average farms. Subsidies for those farms consisted mainly of direct subsidies (in 2013, 66\%). A part of the funds came from the implementation of agri-environmental programmes and LFAs support (respectively in 2004, 1.3\% and 14\%, and in $201327 \%$ and 18\%, adopting all subsidies received under the RDP as 100\%).

In case of farms with mixed production, indicators of the ratio of subsidies to their results significantly increased over the analysed period and exceeded the growth rate for average farms. It resulted from the lower production value from farms with mixed production when compared to average farms - as already mentioned.

Farms specialised in livestock production, on average, acquired lower subsidies than farms in general, both in 2004 and 2013, although that gap decreased over the analysed period. In livestock farms, a major part of the funds came, as in the entire group of the farms of the panel, from direct subsidies (64\%). On the other hand, those farms acquired the largest financial support for their investment activity, and to a much lesser extent participated in environmental measures (in 2013, 18\% of the value of subsidies under the 
RDP were acquired in that respect). Certainly, that use of the funds was affected by their organisation, which often differed from the environmental standards. Owing to the relatively high profitability of specialist livestock production, reorganisation of those farms through agri-environmental subsidies is not a lucrative economic alternative. Specialist livestock farms received a greater stream of LFA funds, when compared to average farms (this was $25 \%$ of all subsidies from the RDP in 2013). These results indicate indirectly the regionalisation of specialist livestock production - their development in areas which are characterised by limited capacity for crop production.

Based on the values of the indicators showing the ratios of subsidies to the selected farm output categories, it may be concluded that livestock farms are less dependent on subsidies - external support, when compared to farms in general and to other analysed groups. This results mainly from the very high production value, which they generate.

\section{Conclusions}

The article presented the proposal for measuring economic sustainability of farms using the data of the FADN. This article adopted the following indicators of economic sustainability, such as: land and labour productivity, land and labour profitability. There were also indicated interactions between economic and environmental sustainability of farms. The analysis included individual farms (in total), organic, with mixed production and livestock specialised farms.

The presented results of the analysis show the changes taking place in farms towards the specialisation of agricultural production, which is more profitable for the agricultural producer, i.e. more sustainable in economic terms, but also less sustainable in environmental terms. Organic farms, despite their definitely worse economic situation, become popular and tend to develop. The relatively low level of production intensity and specialisation of organic farms (this determines their less favourable competitive position) and generated environmental and social benefits are not taken into account in the market transactions.

There is a gap between organic farms and farms with mixed production in relation to average farms and all the more in relation to specialist farms, both in terms of factor productivity and profitability. Organic farms achieve particularly low results of factor productivity and profitability, which, although slightly improved, but the gap between them and average farms increased in the case of factor productivity. Reduction of differences in factor profitability was the result of subsidies, particularly connected with operational activity of farms.

Specialist livestock production are characterised by relatively high economic sustainability, thus reorganisation of those farms through agri-environmental subsidies is not a lucrative economic alternative. Livestock farms are less dependent on subsidies external support, when compared to farms in general and to other analysed groups. This results mainly from the very high production value, which they generate.

The indicators of the ratio of subsidies to the production and economic results illustrate their increasing role in shaping the economic situation of farms (all analysed groups). Linking subsidies with the environmental protection principles in agricultural production also affected the environmental sustainability of farms. 
To sum up, it seems reasonable to provide more support to these farms, that provide services for society and environment.

\section{References}

Goraj, L., Mańko, S. (2009). Rachunkowość i analiza ekonomiczna w indywidualnym gospodarstwie rolnym. Difin. Warszawa 2009. p. 40.

Kociszewski, K. (2014). Ekologiczne aspekty zmian Wspólnej Polityki Rolnej a zrównoważony rozwój polskiego rolnictwa, IN: J.St. Zegar (ed.), Z badań nad rolnictwem społecznie zrównoważonym [23]. Monografie Programu Wieloletniego. No. 100. IERiGŻ-PIB. Warszawa.

Krzyżanowski J. (2015). Wpływ WPR 2014-2020 na zrównoważenie polskiego rolnictwa w świetle dotychczasowych badań i bieżących dokumentów, IN: J.St. Zegar (ed.), Z badań nad rolnictwem społecznie zrównoważonym [31]. Monografie Programu Wieloletniego. No. 6. IERiGŻ-PIB. Warszawa.

Ploeg, J.D. van der. (2009). The new peasantries. Struggles for autonomy and sustainability in the era of empire and globalization. Eartscan. London.

Woś, A., Zegar, J.St. (2002). Rolnictwo społecznie zrównoważone. IERiGŻ. Warszawa.

Wrzaszcz, W. (2014). Sustainability of Agricultural Holdings in Poland. IERiGŻ-PIB. Studia i Monografie. No. 161. Warszawa.

Wrzaszcz W., Prandecki K. (2015). Environmentally sustainable agriculture in Poland - economic assessment. European Journal of Sustainable Development, Vol. 4, No. 2, pp. 429-438.

Wrzaszcz W., Zegar J. St. (2014). Economic Sustainability of Farms in Poland. European Journal of Sustainable Development. Vol. 3, No. 3. pp. 165-176.

Zegar, J.St. (2012). Współczesne wyzwania rolnictwa, WN PWN. Warszawa.

Zegar, J.St. (ed.). (2013). Zrównoważenie polskiego rolnictwa. Powszechny Spis Rolny 2013. Authors: Toczyński, T., Wrzaszcz, W., Zegar J. St., GUS, Warszawa. 